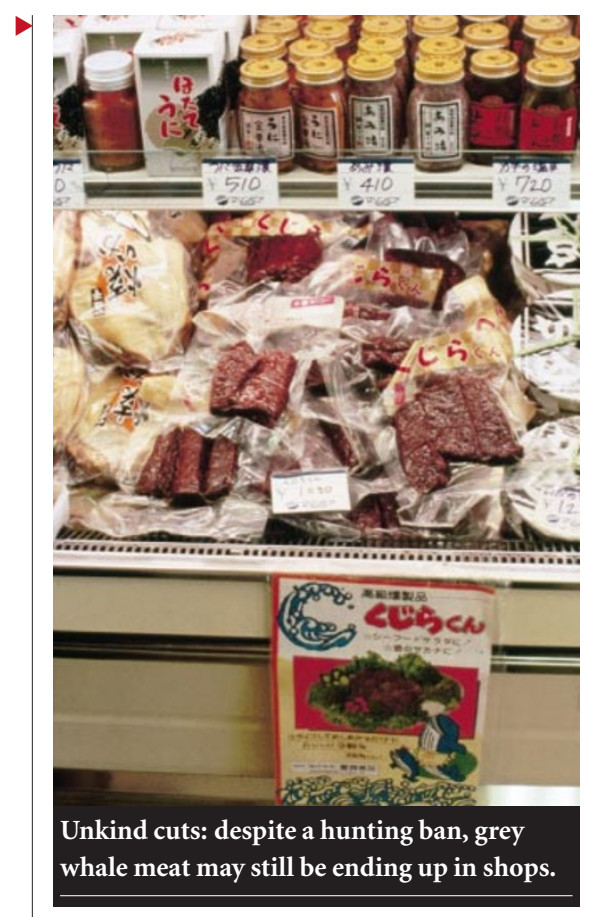

authorities. Some link this to Japanese regulations that allow the local use of meat from whales stranded or entangled in fishing gear regardless of their protective status.

The team believes it is possible that the products came from an Asian grey whale found floating in the Sea of Japan near the northern island of Hokkaido in 1996.

Although the whale was reported as being 'stranded', a later investigation revealed that it had been harpooned, with a 5-6 metre section of its tail expertly severed.

"It is possible that the products originate from long-term stockpiling of whales killed before 1986," says Baker. "But if they prove to be derived from the Hokkaido whale, the practice of stockpiling applies to illegal products, and the meat is being sent to places which could hardly be described as 'local'.

"Either way, undocumented and possibly illegal products from endangered species are turning up in the commercial market, and allowing trade in products from the American population should not be considered until this lack of transparency is solved."

The Fisheries Agency insists its proposed downlisting of the three whale species is not intended to lead to a resumption of trade in whale meat, but rather to pursue appropriate management of the species based on scientific findings.

But Naoko Nakamae, the Japanese representative of the International Fund for Animal Welfare, says such a move would put the Asian stock of grey whales at risk. "Unless the Japanese authority decides to make its data available to all, differentiating the two populations will remain impossible," she says. Asako Saegusa

\title{
US court tests the breadth of patent protection on proteins
}

Washington

Does a patent on a recombinantly produced protein give the owner rights to versions of that protein produced in other ways? This issue is being put to the test in a closely watched battle that opened in a Boston courtroom last week.

The biotechnology company Amgen, based in Thousand Oaks, California, is suing Transkaryotic Therapies (TKT), a small company in Cambridge, Massachusetts, alleging infringement of several patents on its blockbuster drug Epogen. Used to treat anaemia, Epogen is the trade name for erythropoietin (EPO), the hormone that stimulates the production of red blood cells.

Amgen developed the drug by cloning the human EPO gene and inserting it in Chinese hamster ovary cells, which then produce the hormone. US sales of Epogen for treating anaemia in kidney-dialysis patients totalled $\$ 1.8$ billion last year. Johnson \& Johnson, which sells Epogen for other uses under licence to Amgen, generated an additional \$2 billion in sales. Worldwide, the Epogen market is estimated to be worth $\$ 5$ billion a year.

Enter TKT. The company's researchers have developed an alternative way to produce EPO, taking advantage of the fact that all human cells carry the EPO gene, even though it is active only in kidney cells. In TKT's process, a promoter — or 'on-switch' — for the gene is inserted in human cells along with other regulatory and structural elements that guide the promoter to the EPO gene. The gene becomes activated and the cells begin producing the hormone.

TKT plans to market EPO produced in this way in collaboration with Aventis, the giant European drug-maker. It claims that its production process is distinct from Amgen's, so it is not infringing on the company's patents on the EPO gene and EPO production. Indeed, TKT's process does not require knowledge of the gene sequence.

More importantly, the Cambridge company disputes Amgen's patent rights to the EPO protein itself when made by mammalian cells in culture — rights that will be at the centre of the battle in US District Court. TKT and its advocates argue that Amgen is asserting far too broad a claim to a naturally occurring protein that was well characterized decades before Amgen cloned the gene and was granted its first patent in 1987. Indeed, Amgen scientists worked backwards from the protein's known amino-acid sequence to deduce the gene sequence.

If TKT prevails against Amgen, the implications would be considerable for Amgen's lucrative EPO market. They could also be felt by companies that have commercialized other therapeutic proteins such as interferon and Neupogen, another Amgen product.

TKT says that it has six additional proteins in its therapeutic pipeline, all made by the same promoter-insertion process. If it were to bring any of them to market - and presuming it prevailed in the inevitable court battles that would ensue - it could make considerable dents in what until now have been relatively exclusive and lucrative markets.

As a result, if TKT wins the lawsuit, "the industry may kind of go into shock", says Eric Schmidt, a biotechnology analyst at S. G. Cowen Securities in New York.

Amgen itself predicts dire consequences in such an event. "The real question is how strong is the US patent system," Gordon Binder, Amgen's chief executive, told The New York Times after the first day of preliminary court proceedings last week.

Some analysts back Amgen. "We believe that the Amgen patents do cover the TKT EPO product, if not the production process," says Dennis Harp of Deutsche Banc Alex. Brown, a global financial services company.

But others disagree. "If Amgen prevails, it suggests that US patents are so restrictive that it would actually discourage legitimate innovation," says Jonas Alsenas, an analyst at IND Bearings in New York. "If by solving half the problem you get rights to the full solution to the problem, that's not fair."

TKT declines to comment because the case is in litigation. Earlier this year, Richard Selden, its chief executive, told The New York Times: "We think that we're doing something fundamentally different" from Amgen.

David Kaye, an Amgen spokesman, says "We're confident in our patent position". The full trial of the case, which Amgen filed in 1997, is expected to begin in May. Whatever verdict is reached is almost certain to be appealed against.

Meredith Wadman

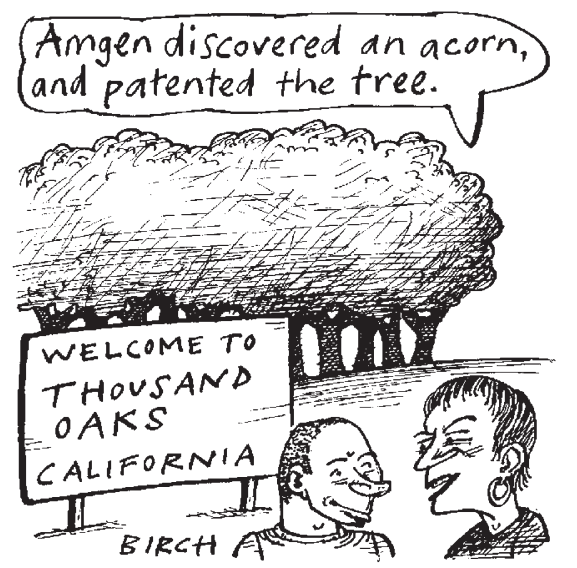

